\title{
How is English Language Policy Translated to Classroom Practice? (A Case Study in an Indonesia Primary School)
}

\author{
Yustika Nur Fajriah ${ }^{1}$, Anne Ratna $S^{2}$, Pipih Setiawati ${ }^{3}$, Lucky R Nurjamin ${ }^{4}$ \\ \{yustikanurfajriah@institutpendidikan.ac.id ${ }^{1}$, anners@institutpendidikan.ac.id² \\ pipih@institutpendidikan.ac.id ${ }^{3}$, luckyrahayu@institutpendidikan.ac.id $\left.{ }^{4}\right\}$ \\ Institut Pendidikan Indonesia, Jalan Terusan Pahlawan No.32 Sukagalih - Tarogong Kidul, Garut, \\ Indonesia $^{1234}$
}

\begin{abstract}
By the latest education policy that English is removed in primary school level's intra-curriculum, this study is a preliminary endeavour to investigate the pedagogical practice of the policy, particularly in a private elementary school in Indonesia. To achieve that aim, two English teachers were involved as the research participants. In collecting the data, non-participant classroom observations, as well as semi-structured interviews, were utilized. The data were then examined using inductive analysis. The most disgusting result to emerge from the data is that English language teaching in primary school needs thoughtful attentiveness from the government. The policy in removing English as the compulsory subject in elementary school level has effects on the bias goal of teaching, unstructured materials, as well as monotonous teaching practices. Therefore, the evidence of this study points toward to the idea that the government and related policymakers have to adjust the primary schools which still keep involving English in their curriculum; that is, by determining the standard of English teaching as well as controlling the teaching programs under a particular association.
\end{abstract}

Keywords: education policy, pedagogical practice, learning materials, teaching method

\section{Introduction}

The latest language policy as remarked in curriculum 2013 highlights the deletion of English in the primary school curriculum. This means that the government does not suggest elementary schools to introduce English at that level. Further, this rule also apparently confirms that there is no standardized curriculum of English for elementary students. Hence, schools providing English program have their authority to develop, adapt, or adopt the curriculum for English subject.

The new adjustment as mentioned above stimulates different responses from education experts, schools, teachers, and parents. Some of them support 'no English for kids' based on 
some reasons; jeopardizing nationalism [1], facing the immaturity of students' cognitive capacity [2]. Nevertheless, other people claim that familiarizing English at an early age is meaningful to undertake. As an instance, the theory of LAD (language acquisition device), claiming that children are naturally able to learn their second language since the process is not different from their first language acquisition [3]. Another premise also comes from Krashen with his CAH (Critical Age Hypothesis), revealing that children biologically have bouncy brain [4]; therefore, they will not have any barrier to master any languages. This is also supported by parents' great pressure to the government in providing English class for elementary school level [5], [6].

In response to the issue above, numerous related studies focusing on English teaching in primary school stages have been accomplished. As an instance, a study was conducted to explore the teachers' voice on the absence of English from primary school curriculum [7]. This study was undertaken to 20 teachers from English and non-English background. The data were gained from the interview, observation, and document analysis. This study reveals that most participants believe in the importance of English teaching at the primary school level. Therefore, English must be included as a compulsory subject and need professional care from the policy makers. Another research-based report also was written with the emphasis of portraying English teaching as the local content in Lampung province [8]. Some of the results in this study claim that there was no fixed curriculum used; therefore, the teaching and learning process did not run systematically. Also, the teachers also were not equipped to teach at this level because all of them graduated from schools which prepared them to teach junior and senior high school levels.

Seeing some examples of studies above, it is obvious that the further studies focusing on how English is taught at the elementary level after the latest change of English policy in Indonesia are necessary to do. Hence, this study aims at investigating how English language policy is reflected on the primary school level through English teaching practice.

\section{Methods}

To achieve the aim above, this study was done under a single case study approach [9], [10], [11]. In gaining the data, one-week observation, as well as semi-structure interview, were conducted. Specifically, the non-participant observation was selected due to figure out the teaching process happening in the classroom, the results were then confirmed by interview sessions to the teachers. Both of the data were then analysed using inductive analysis; covering, coding, analysing, interpreting, and drawing the conclusion [12].

Moreover, one private elementary school in Indonesia served as the research site. This school was chosen as the research site because of its consistency in having English subject in spite of the government's latest policy in deleting this subject at this level. Moreover, as profiles of this site, this school is a private Islamic school located quite far from the centre of Garut. This school was founded by a quite big foundation which also has other school programs such as kindergarten, junior high school, senior high school, and higher education school.

Specifically, the participants of this study are two English teachers with pseudo-names, RN and TY. As a brief profile, RN is included as a young male teacher who works as an English teacher in the fourth grade and the official operator of this school. The other participant is an adult female teacher, TY, teaches English in class six. Regarding educational background, both of them are not from English education yet from Islamic religion major. 


\section{Results and Discussion}

This part elaborates the research findings including the teachers' method in teaching as well as the materials given in the classroom. Details of the data are provided below.

Table 1. the comparison of English teaching in grade four and six

\begin{tabular}{|c|c|c|c|c|c|c|}
\hline $\begin{array}{l}\text { Gra- } \\
\text { de }\end{array}$ & $\begin{array}{l}\text { Focus of } \\
\text { materials }\end{array}$ & $\begin{array}{l}\text { Teachi } \\
\text { ng me- } \\
\text { thod }\end{array}$ & $\begin{array}{l}\text { Teacher's } \\
\text { educational } \\
\text { background }\end{array}$ & $\begin{array}{l}\text { Learning } \\
\text { sources }\end{array}$ & $\begin{array}{l}\text { Curricu- } \\
\text { lum }\end{array}$ & $\begin{array}{l}\text { Adminis- } \\
\text { trative } \\
\text { documents }\end{array}$ \\
\hline $\begin{array}{l}\text { Class } \\
4\end{array}$ & $\begin{array}{l}\text { Vocabula } \\
\text { ry items }\end{array}$ & GTM & $\begin{array}{l}\text { S1(non } \\
\text { English } \\
\text { education } \\
\text { background) }\end{array}$ & $\begin{array}{l}\text { A } \\
\text { textbook } \\
(2013 \\
\text { curriculu } \\
\text { m book } \\
\text { from the } \\
\text { governme } \\
\text { nt) }\end{array}$ & $\begin{array}{l}2013 \\
\text { curriculu } \\
\mathrm{m}\end{array}$ & $\begin{array}{l}\text { Lesson } \\
\text { plan \& } \\
\text { syllabus } \\
\text { are } \\
\text { available }\end{array}$ \\
\hline $\begin{array}{l}\text { Class } \\
6\end{array}$ & $\begin{array}{l}\text { Daily } \\
\text { expressio } \\
n\end{array}$ & GTM & $\begin{array}{l}\text { S1(non- } \\
\text { English } \\
\text { education } \\
\text { background) }\end{array}$ & $\begin{array}{l}\text { A } \\
\text { textbook } \\
(2013 \\
\text { curriculu } \\
\text { m book } \\
\text { from the } \\
\text { governme } \\
\text { nt) }\end{array}$ & $\begin{array}{l}\text { School- } \\
\text { based } \\
\text { curriculu } \\
\mathrm{m}\end{array}$ & $\begin{array}{l}\text { No lesson } \\
\text { plan and no } \\
\text { syllabus. }\end{array}$ \\
\hline
\end{tabular}

From the table above, there are three points to discuss; the qualification of the teachers, the method used in teaching, the administration used; curriculum, syllabus, and lesson plan.

First, due to the background of those two teachers, it is inferred that the school does not equip the English class with the relevant qualification of teachers. This is in line with the notion that English class in elementary school is mostly carried by those who come from other subject range; science, other languages, and others [13]. Therefore, both of them have not been trained to have good performance and competence in teaching English. As confirmed by the interview sessions, both teachers admitted that they only learn by themselves with the help from the textbook used only. This condition is contrary to the ideal English teaching for young learner requirement; that is, fulfilling good English proficiency and language teaching skill [14].

Second, the Grammar Translation Method was employed in those two classes. As an example, the English teacher in class 4 wrote down English words and their translation in Bahasa Indonesia. Afterwards, students were asked to copy those words in their books. The same depiction was also seen in class 6 . The teacher taught some daily expressions by writing the materials. After that, some students were invited to read the dialogues, and others paid attention to them. The method used was not appropriate to the students' characteristic as young learners. This is in line with the statement that different from adults, children need special treatments to study, they are, physical activities are involved in the classroom, students have to be engaged in here and now situation [15], [16], [17]. In response to this, other teaching techniques are assumed appropriate for kids; as examples, Total Physical Response (TPR) and 
games. This is claimed beneficial to stimulate students' motivation and enthusiasm in the class since they will be engaged in physical activities.

Third, the problems were found in the teachers' administration; such as lesson plan and syllabus. Specifically, English teacher in class six was not consistent in implementing curriculum. It was reflected by using 2013 curriculum book under School-Based Curriculum. In addition to this, this teacher did not have any lesson plan and syllabus to teach. As confirmed by the interview, she said that she only depended on the textbook, and there was no clear control and supervision from the school. Better than that, the teacher in class four had complete administration in terms of lesson plan and syllabus. However, incongruity was seen from the technique of teaching in practice and the written document. Lecturing technique under GTM was used, instead of a scientific approach as mentioned in the lesson plan. It means that the steps involving observing, questioning, experimenting, associating, and networking were not implemented at all.

To sum up, the teachers had their authorities to determine the aim and the content of teaching, as well as to choose the learning sources and teaching methods. This finding confirms the previous study that in one of the big cities in Lampung province, Indonesia, English teaching in primary schools does not show any well-defined attainment due to the unstructured plan and practice [8]. This condition is also claimed as the effect of the government's unwillingness to compromise English officially as the second language in Indonesia [18]. Parallel to this, the status of English as non-compulsory subject remained problematic for schools [19] in determining so many aspects; such as the aim of English teaching and its relevance to the teaching technique, teaching materials, and assessment. Seeing this, in spite of the efficacious accomplishment of language policy for Bahasa Indonesia, English language policy in Indonesia is claimed ineffective [20].

\section{Conclusions}

The conclusion of this study is that the government should do an earnest appraisal to English language policy in the education sector; especially, in the primary school phase. This is due to some considerations. First, in spite of the absence of English in intra-curriculum, numerous schools are still consistent with having English subject in their program. Second, the parents' expectation of schools in introducing English subject in primary school is undisputable. Third, English teachers in primary school level still face some obstacles; teachers' qualification; teaching method, and learning sources.

\section{Implication}

From the results as presented above, it is important to note that the government and relevant policymakers should follow up the recent English Policy in primary education into its clear-cut standard, procedure, and practice. One of the efforts is by officialising English teachers for the elementary school. Another solution is by founding a certain legal association which functions to manage control English teaching in the primary level; therefore, the schools which have any intentions to have English program in this basic level should fulfil any criteria given by the government. 


\section{Reference}

[1] Hadisantosa, N.: Insights from Indonesia. In R. Johnstone (Ed.). Learning through english: Policies, challenges and prospects. London: British Council. Vol., pp. 24-46 (2010)

[2] Zein, M. S.: Elementary english education in Indonesia: Policy developments, current practices, and future prospects: How has Indonesia coped with the demand for teaching English in schools? English Today. Vol. 33., pp. 53-59 (2016)

[3] Chomsky, N.: Aspects of the theory of syntax. Cambridge, Mass.: MIT Press Dardjowidjojo. (1965)

[4] Gursoy, E.: The critical period hypothesis revisited: the implications for current foreign language teaching to young learners. Journal of language teaching and research. Vol. 2 757-762 (2011)

[5] Baldauf Jr., R. B., Kaplan, R. B., Kamwangamalu, N., \& Bryant, P.: Success or failure of primary second/foreign language programmes in Asia: what do the data tell us? Current Issues in Language Planning. Vol. 12., pp. 309-323 (2011)

[6] Chodidjah, I. Innovative in-service teacher training for basic education in Indonesia. Jakarta: LB LIA. (2010)

[7] Kaltsum, H.U. Tanggapan perseptual guru Bahasa inggris di SD se surakarta terhadap kebijakan pelaksanaan mata pelajaran Bahasa inggris di sekolah dasar. Profesi Pendidikan dasar. (2014)

[8] Sutarsyah, C.: Pembelajaran Bahasa inggris sebagai muatan local pada sekolah dasar di propinsi lampung. AKSARA Jurnal Bahasa dan Sastra. Vol. 18., pp. 35-43 (2016)

[9] Bogdan, R., \& Biklen, S. K.: Qualitative research for education. Boston: Allyn and Bacon. (1992)

[10] Nunan, D.: Research methods in language learning. United States of America: Cambridge University Press. (1992)

[11] Cresswell, J. W.: Educational research. New Jersey: Prantice Hall.(2010)

[12] Liu, L.: Using generic inductive approach in qualitative educational research: a case study analysis. Journal of Education and Learning; Vol. 5., pp. 129-135 (2016)

[13] Bautista, T.: Language planning and policies in the developing nations. The National Center for Teacher Education Research. Philippine Normal University Research (thesis) (2017)

[14] Lestari, L.A.: Should English be a compulsory subject? BAHASA DAN SENI. Vol. 31., pp. 197-213 (2003)

[15]Pinter, A.: Teaching Young Language Learners. Oxford: Oxford University Press. (2006)

[16] Musthafa, B.: Teaching English to young learners in Indonesia: essential requirements. EDUCATIONIST. Vol. 4., pp. 120-125 (2010)

[17] Juhana.: Teaching English to young learners: some points to be considered. Asian Journal of Education and e-learning. Vol. 2., pp. 43-46 (2014)

[18][18] Zein, S.: Language in education policy on Primary EFL: the case of Indonesia. Int. J. of Pedagogies \& Learning. Vol. 12., pp. 133-146 (2017)

[19] Hawanti, S.: Implementing Indonesia's English language teaching policy in primary schools: the role of teachers' knowledge and beliefs. International Journal of Pedagogies and Learning. Vol. 9., pp. 162-170 (2014)

[20] Lauder, A. The status and function of English in Indonesia: a review of key factors. MAKARA, SOCIAL HUMANIORA. Vol. 12., pp. 9-20 (2008) 
